\title{
The chert quarrying and processing industry at the Piatra Tomii site, Romania
}

\author{
Otis Norman Crandell ${ }^{1}$, Cristian Ioan Popa ${ }^{2}$ \\ 1. Babes-Bolyai University, Department of Geology, Cluj-Napoca, Romania. Email: otis.crandell@ubbcluj.ro \\ 2. "1 Decembrie 1918" University of Alba Iulia, Department of History, Alba Iulia, Romania. \\ Email: cristian.popa@uab.ro
}

\begin{abstract}
:
Fieldwalking surveys in 2007 and 2008 revealed a moderate sized settlement on Piatra Tomii Hill (Alba County, Romania) which was considered of interest because of its location on top of a natural source of chert, and the large amount of chert artefacts found on the surface. In 2009 the site was excavated during which one of the objectives was to learn more about the chert mining and processing at the site. The ratio of artefact types and lack of use-wear suggests that not only was raw material being extracted at the site, but tools were also being produced locally before being exported. The 2009 excavations also revealed what appear to be the remains of pit quarrying and possibly fire cracked limestone and debris. These finds provide technical insight into potential chert extraction techniques utilised in the Late Chalcolithic and Early Bronze Age. As well, this is as yet the only reported settlement in the Transylvanian basin involved in chert extraction (either quarrying or mining). Given the settlement's affluence, especially considering its relative isolation, it is likely that the chert industry here was important to communities in the vicinity. Indeed artefacts found at contemporary sites in the Mureș Valley appear to have been made from the same or a similar chert. This paper gives an introductions to the site, describes the artefacts and features found there and provides possible interpretations regarding the processing and export industry, as well as the methods of extracting the raw material during this period.
\end{abstract}

Keywords: chert; quarrying; lithic artefacts; Chalcolithic; Romania

\section{Introduction}

One of the main focuses of the excavations was to learn more about the chert industry at the settlement. In particular, there was an interested in how the material was being extracted and how it was being processed afterwards. For this, the research at this site has investigated areas potentially linked to chert extraction. There was also an interest in the general lives of the people who inhabited the settlement so a dwelling was partially excavated. Excavations of the dwelling introduced a new form of Coţofeni dwelling architecture which also became a topic of interest.

Published by the School of History, Classics and Archaeology, University of Edinburgh ISSN: 2055-0472. URL: http://journals.ed.ac.uk/lithicstudies/

This work is licensed under a Creative Commons Attribution 2.5 UK: Scotland License. 


\section{Location}

The Piatra Tomii site is located in the south-western part of the Transylvanian basin, about half way along the course of the Mureș valley. More precisely, it is located in the Southern Apuseni Mountains at a height of about 300m above the Mureș valley (about $860 \mathrm{~m}$ above sea level). The site itself is located on the Piatra Tomii hill (from which the site derives its name) on the outskirts of Răcătău village (Blandiana commune), Alba county. (See Figure 1.) The site is connected to the Mureș valley by the Răcătău stream (to the southeast of the hill) which flows down from the mountains and connects to the Mureș valley near the modern town of Blandiana. By following the valleys, the site is located about a $6 \mathrm{~km}$ walk from Blandiana village to the south and about $12 \mathrm{~km}$ from the Mureș River.

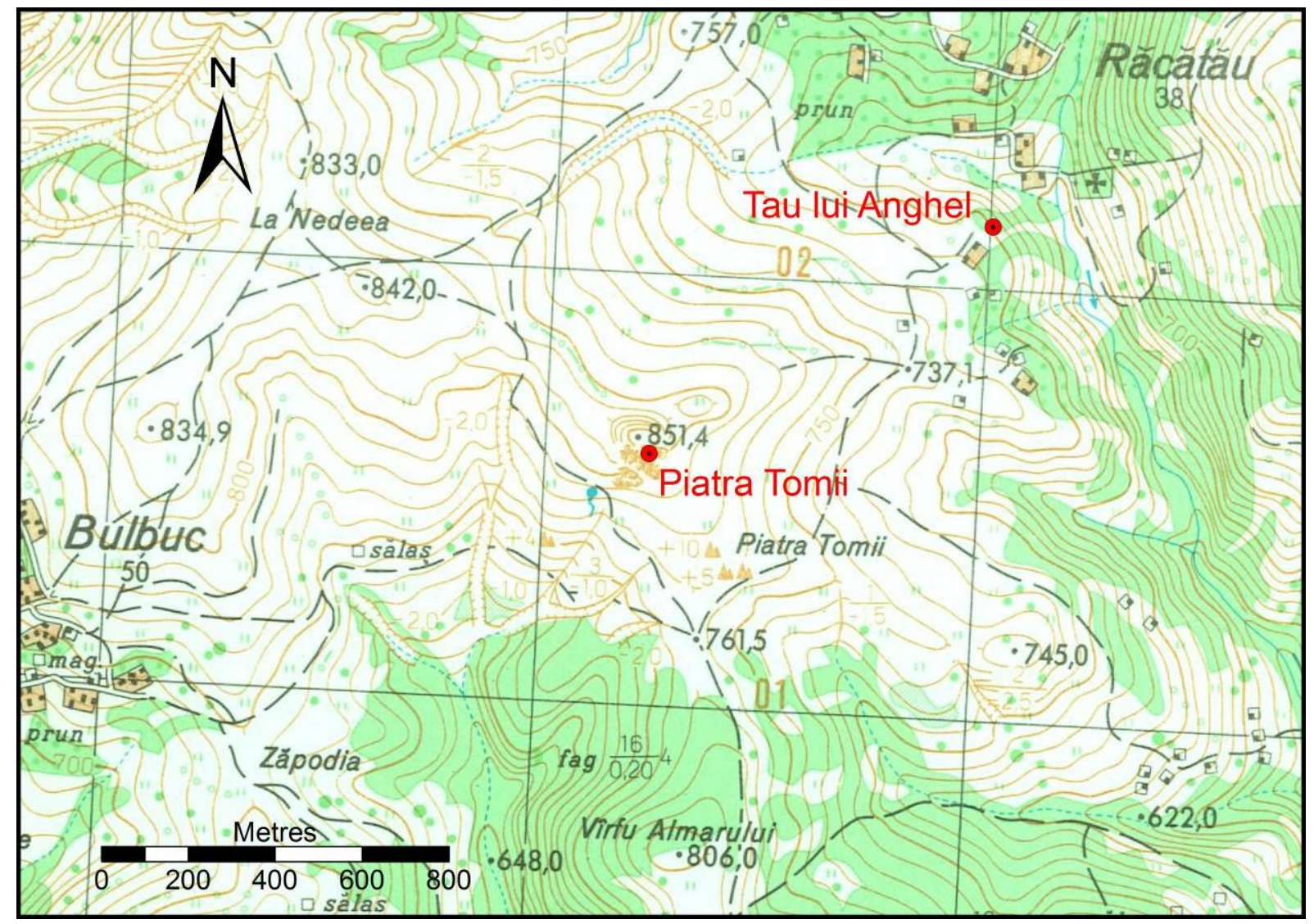

Figure 1. Topographic map of the area around Piatra Tomii. (From Romanian Topographic Map L-34-071-D-c, $2^{\text {nd }}$ Edition, 1:25,000 scale series)

Piatra Tomii hill is in fact a late Jurassic karst tower covered on most sides by a thin layer of topsoil (Giușcă et al. 1967). (See Figure 2.) This limestone outcrop appears to have been tilted over time. What was likely the original top, is now a side of the hill sloping down to the south. The rock has also cracked on the south-western side, causing terraces in some of the cracks which filled in with dirt as well as several deep cracks in the hill. Due to the natural shape of the rock, several terraces have also formed naturally on its south-western, sloped side. Most of the natural surfaces (whether exposed or buried) are worn relatively smooth by weathering. Several springs are located within $100 \mathrm{~m}$ of the hill. The peak of the hill is about $28 \mathrm{~m}$ above its base and the entire hill has a surface area of about $0.2 \mathrm{ha}$ (being about 200$250 \mathrm{~m}$ at its widest). The area around the hill is a plateau used today primarily for grazing sheep. 

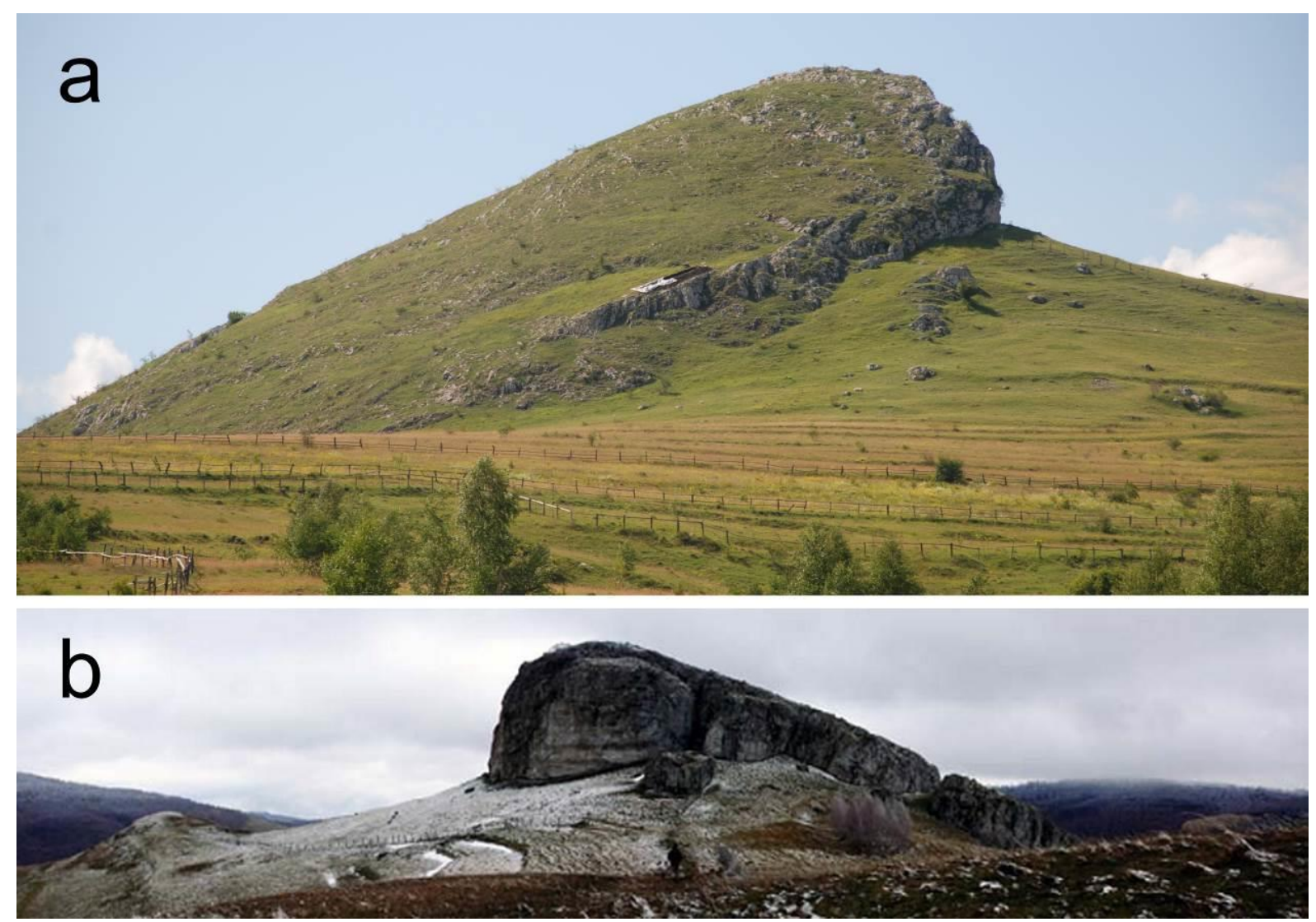

Figure 2. a) Piatra Tomii hill viewed from the east. The trench in Section 1 can be seen in the centre of the photo. b) Piatra Tomii hill viewed from the west.

\section{History of Research}

The site was first reported in the literature by Gábor Téglás at the turn of the $20^{\text {th }}$ century (for example, Téglás 1901: 21; 1902b: 13; 1902a: 21). The site is mentioned in various later reports, although its location is incorrectly associated with the village of Băcăinţi (Roska 1941: 54, nr. 52; 1942: 44, nr. 156; Roman 1976: 79, nr. 194; Moga \& Ciugudean 1995: 52, nr. 15.1; Ciugudean 2000: 64, nr. 56). In 1996, the settlement was rediscovered by Nicolae M. Simina. In 2000 the first archaeological survey and evaluation of the area was conducted by a team consisting of Cristian Ioan Popa, Nicolae Simina and Ovidiu Ghenescu. In the autumn of 2007, Popa organised a fieldwalk survey with Daniel Tentiş Marius Râza, Teodor Muntean, students from the University in Alba Iulia. During the first fieldwalk survey, Otis Crandell was invited along because a large number of chert artefacts had also been found at the site. Upon arriving at the site, it was realised right away that the site is located on an outcrop of limestone which contains chert nodules and lenses. Samples of the chert from the limestone outcrop were taken in 2007 and petrographically analysed in 2008. Further fieldwalk surveys were carried out in 2008. Excavations were carried out at the site by Popa and Crandell in 2009. (See Figure 3 and Figure 4.) These excavations investigated the unusual architectural aspects of the settlement as well as areas potentially linked to chert extraction. A rough topographic survey was carried out at that time. (See Figure 5.) A follow up excavation was carried out in 2010 along with resistivity, magnetometry and topographic surveys. The first images of archaeological materials from this site were published in 2012 by Popa (2012: 12-14, Fig. 1, 8, 10). 


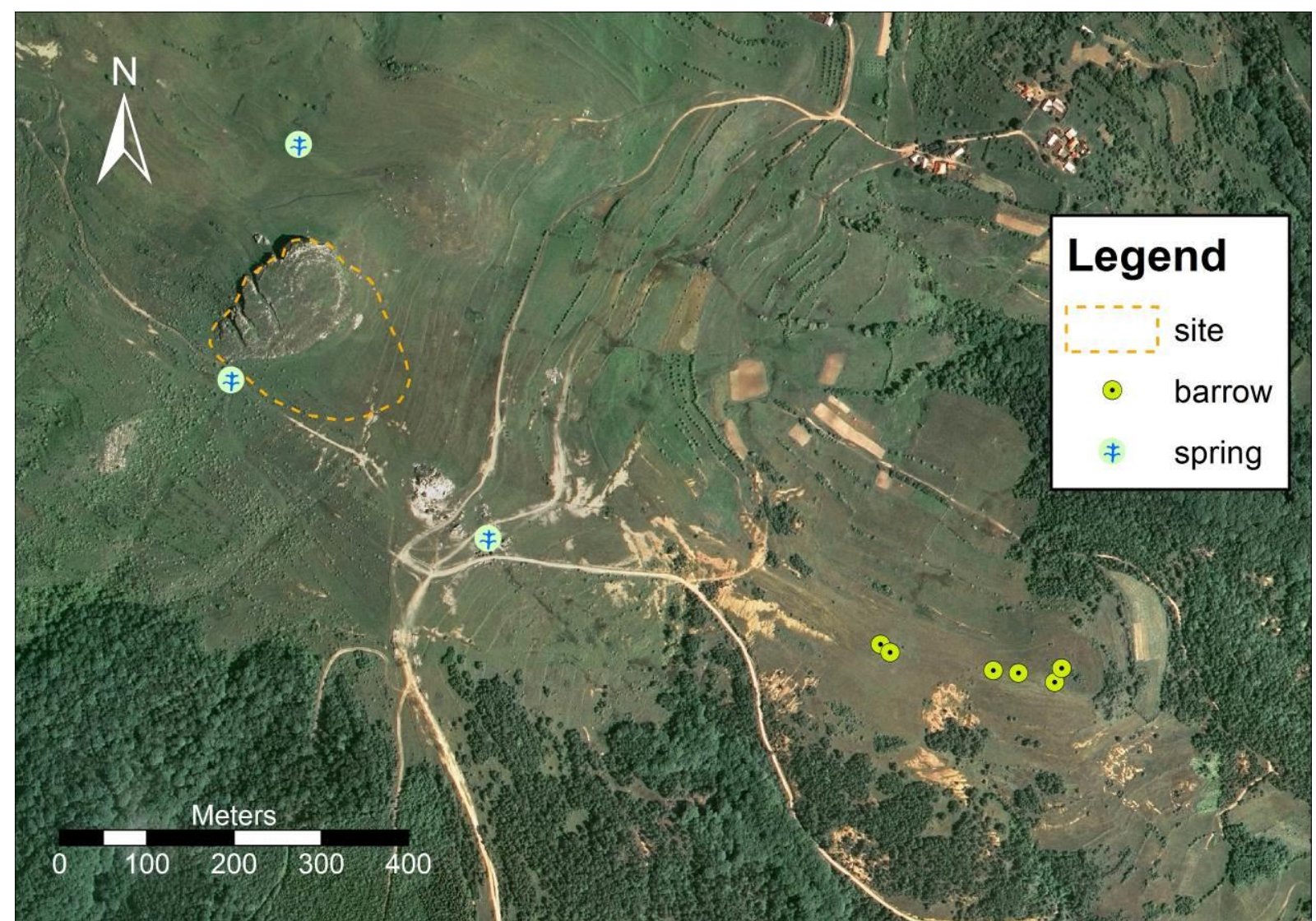

Figure 3. Aerial view of the area around the archaeological site. (Aerial photo from ANCPI orthophoto dataset.)

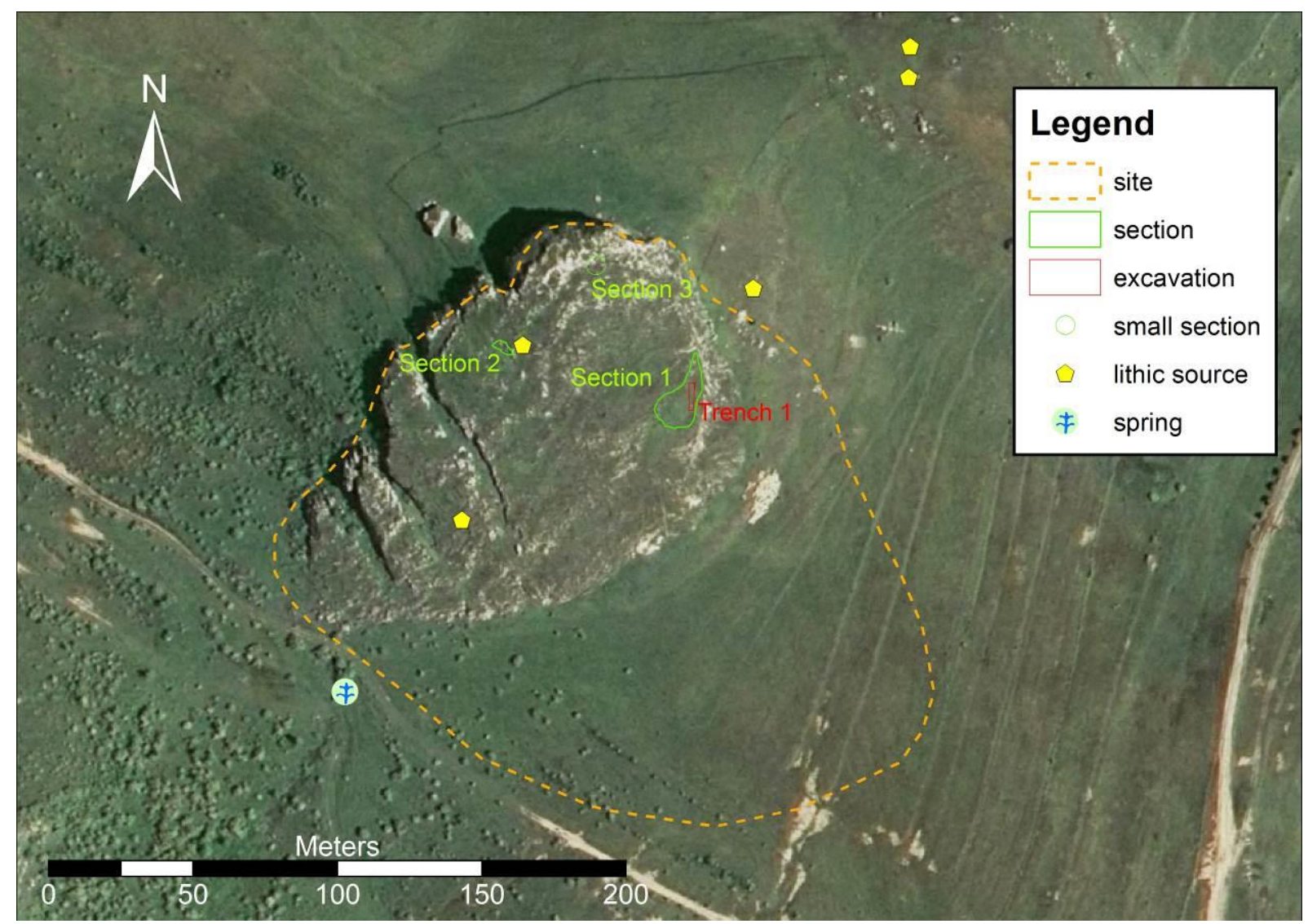

Figure 4. Aerial view of the Piatra Tomii archaeological site around the hill. (Aerial photo from ANCPI orthophoto dataset.) 


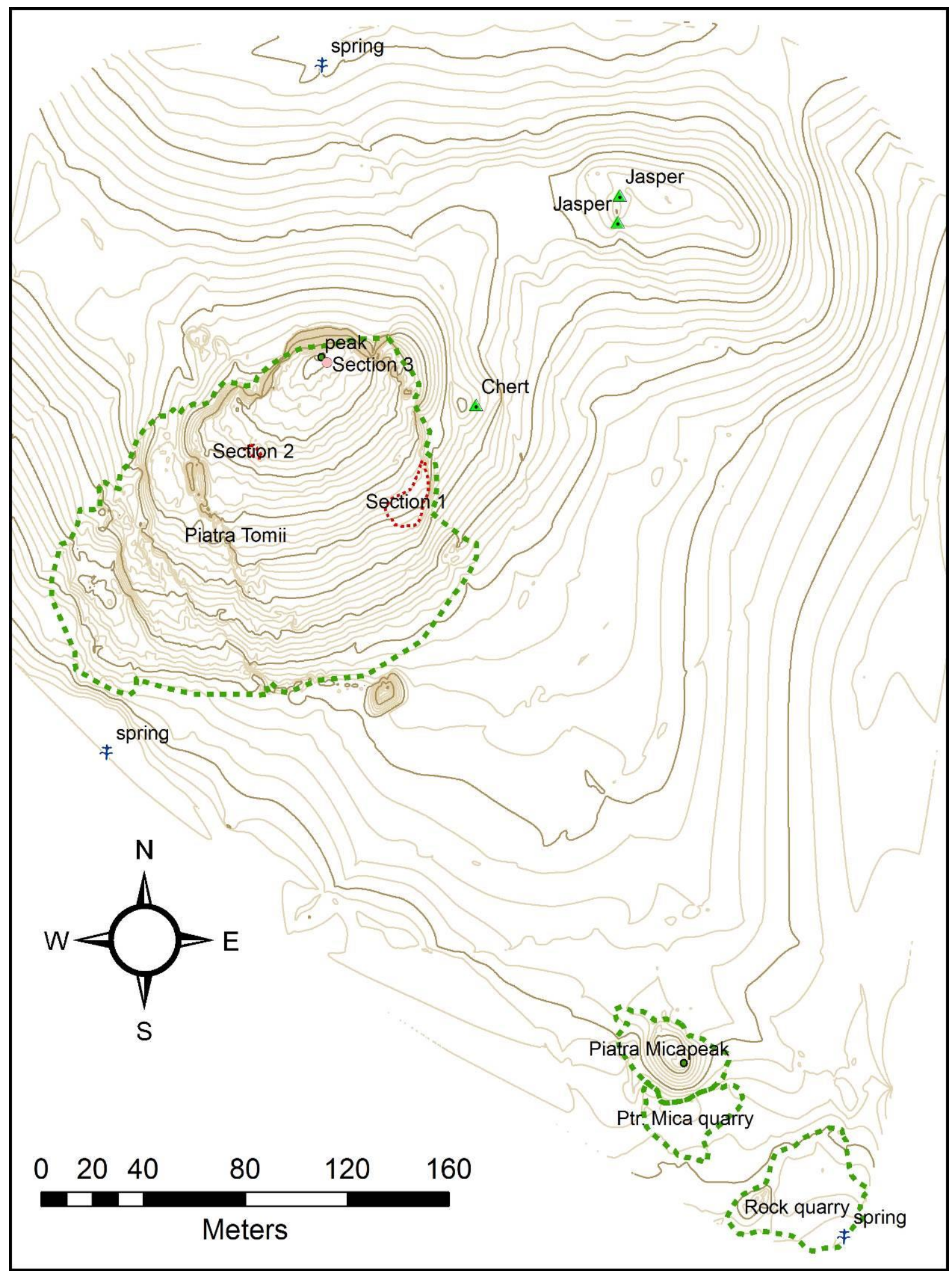

Figure 5. Topographic map of the Piatra Tomii site (topographic survey by the authors, site data recorded during the 2009 excavation and previous field walking surveys). The areas marked by green dashed line represent the main physical features around the site. 


\section{Chronology of the Site}

In and around Piatra Tomii hill, archaeological remains have been found that date from the Neolithic until the Late Iron Age. Vinča (possibly phase B) ceramics were found in Section 3. Petreşti ceramics were found in Section 3 and at the lower levels of the platform dwelling in Section 1. The majority of artefacts, features, and in particular the surface finds from this site come from the latter part of the Cotofeni culture (phase III-b). There is an Early Bronze Age barrow field near the hill. A few shards of Dacian ceramics were found on the hill.

\subsection{Pre-Coțofeni}

During test pitting in 2009, Vinča and Petreşti type pottery were found at the site (for example, see Figure 6), indicating that the site was in use long prior to the arrival of the Coțofeni population (and possibly abandoned until the late Coțofeni people arrived). The potsherds were found in and next to a possible chert extraction pit. This may indicate a relationship with chert extraction at the site but the evidence is insufficient to make this determination at present. Petreşti type pottery was also found in the lower levels of the platform dwellings excavated in 2009. Whether there was a permanent Vinča or Petreşti settlement, or whether these people only visited the site to extract chert is unclear.
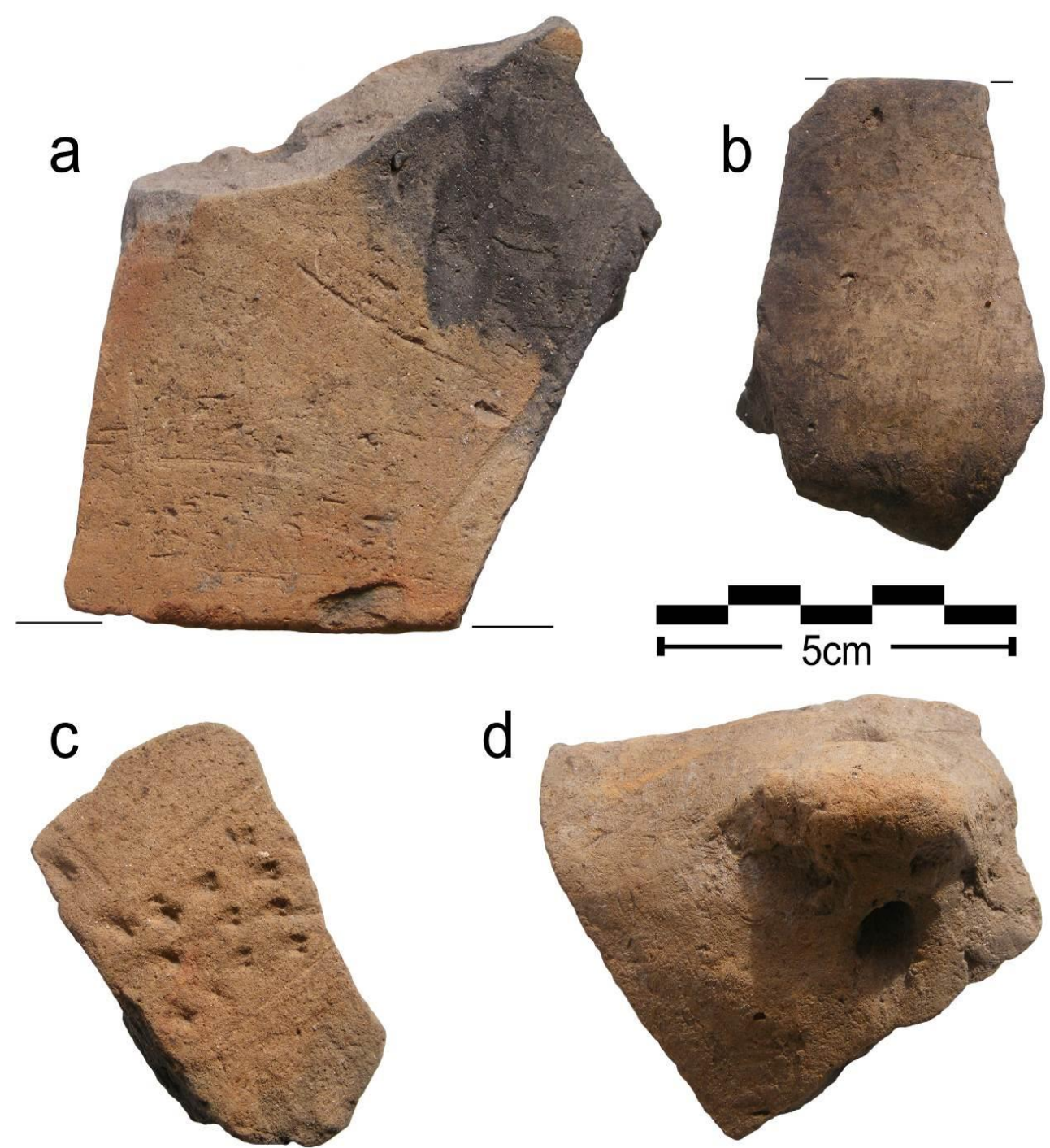

Figure 6. Petrești (a) and Vinča (b-d) culture pottery discovered at the Răcătău-Piatra Tomii site. 


\subsection{Coțofeni}

Primarily this site is known for the Late Chalcolithic to Early Bronze Age settlement. The vast majority of surface finds from the Piatra Tomii site are associated with the end of the Cotofeni culture (phase 3-b). Based on surface finds, test pitting, and initial excavation trenches, it appears that there was a Coţofeni settlement on the slope of the hill as well as the field at the bottom of the slope.

\subsection{Post-Coțofeni}

Fieldwalks revealed a barrow field nearby. (See Figure 3.) Excavation on one of the barrows was started in 2009. Because the excavation of this feature has not been finished, the dating of the barrows as well as possible funerary function have not yet been established. Most likely though, they belong to a later culture of the Early Bronze Age, such as those found at other sites elsewhere in the Apuseni Mountains. As yet, the relation between the barrow field and the settlement has not been established (if there even is one). Similarly, no other Bronze Age settlement has been located in the vicinity.

Although Dacian (Late Iron Age) pottery was found at the site, it was very rare. One ceramic fragment was found in the trench where the Coţofeni dwellings were excavated. Local villagers have reported that a Dacian coin was found here but this information is as yet unverifiable.

\section{Field Survey and Excavation Finds}

\subsection{Chipped Stone Artefacts}

From Section 1 (the dwelling and platform) 111 chert artefacts were found. (For examples, see Figure 7.) Of these, flakes were the most common artefacts. There were 97 flakes, 26 having what appeared to be original outer surfaces of the raw material (cortex or more weathered surfaces) and 71 having all interior surfaces. There were 7 blades or blade fragments, representing $6 \%$ of the chert artefacts from this section. There were also 5 scrapers and three cores. A few lithic artefacts were found in Section 2 (the location of a modern poaching and possible quarrying pit) but given the disturbed nature of this section, the number of artefact types from this section will not be discussed at present. Very few artefacts were found in Section 3 (the upper pit formation). The artefacts that did come from this section were mainly pottery and polished stone. At this site, flakes were by far the most commonly found type of chert artefact among the surface finds from field walk surveys on and around the hill. Because the fieldwalk surveys were not conducted with uniform detail, the exact number of those artefacts is not discussed here at this time.

\subsection{Polished Stone Artefacts}

One fragmented stone axe was found associated with the dwellings in Section 1. Another stone axe was found by a local villager nearby. He claimed that the axe was found at a point named "Tău lui Anghel". The axe from "Tău lui Anghel" may be connected to occupational activities in the area of those who lived at Piatra Tomii. At present it is not believed that there is a settlement or dwelling at this location. Both axes were carved from igneous rock and perforated using some form of drill. (See Figure 8.) 


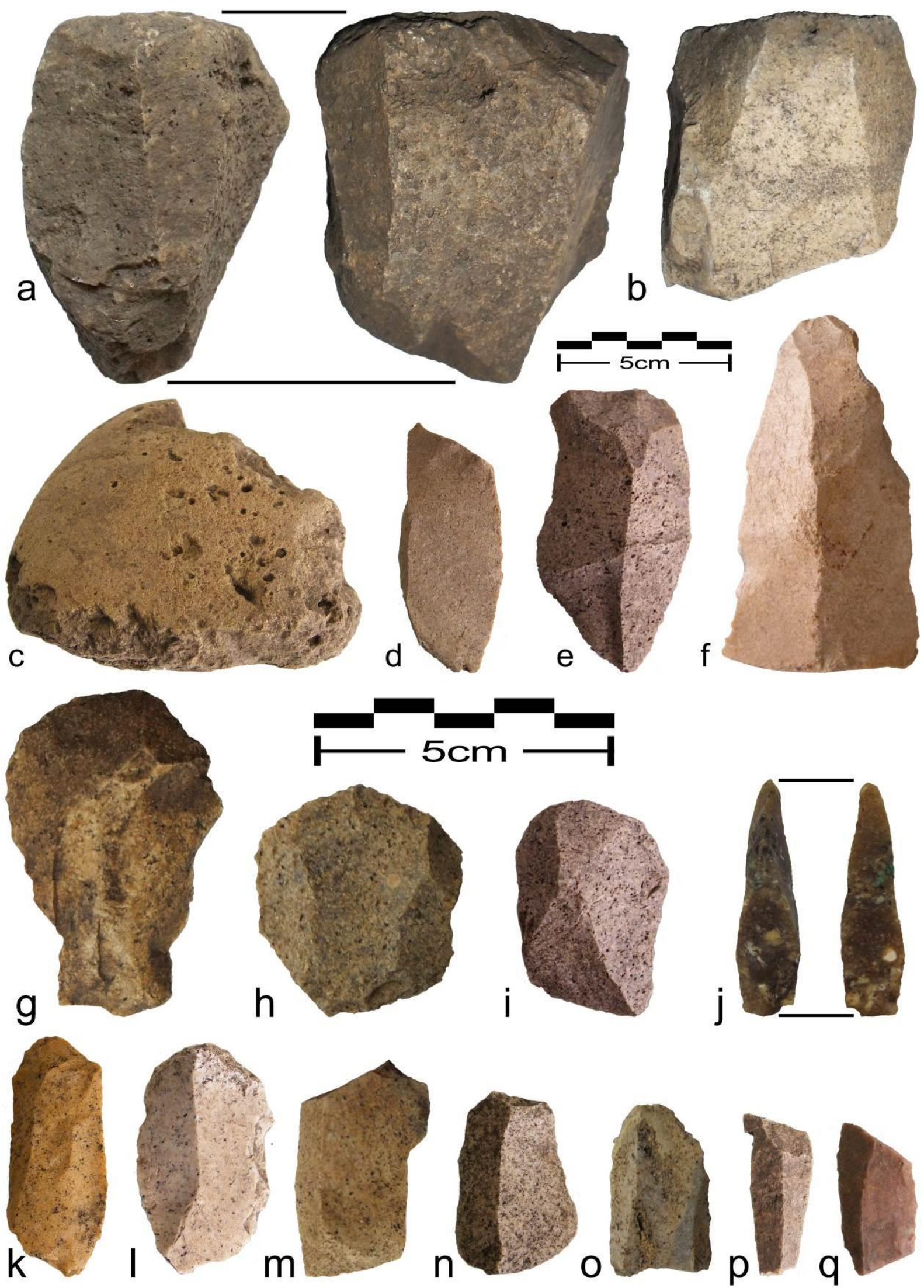

Figure 7. Examples of chert artefacts from the site. a) and b) cores; c) fragment of a hammer stone, pounding stone or grinding stone; d) to f) blades; g) to i) scrapers; j) a perforator; k) to q) blades or blade fragments. (Artefacts $a$ to $f$ are at the same scale as each other. Artefacts $g$ to $q$ are at the same scale as each other.) 


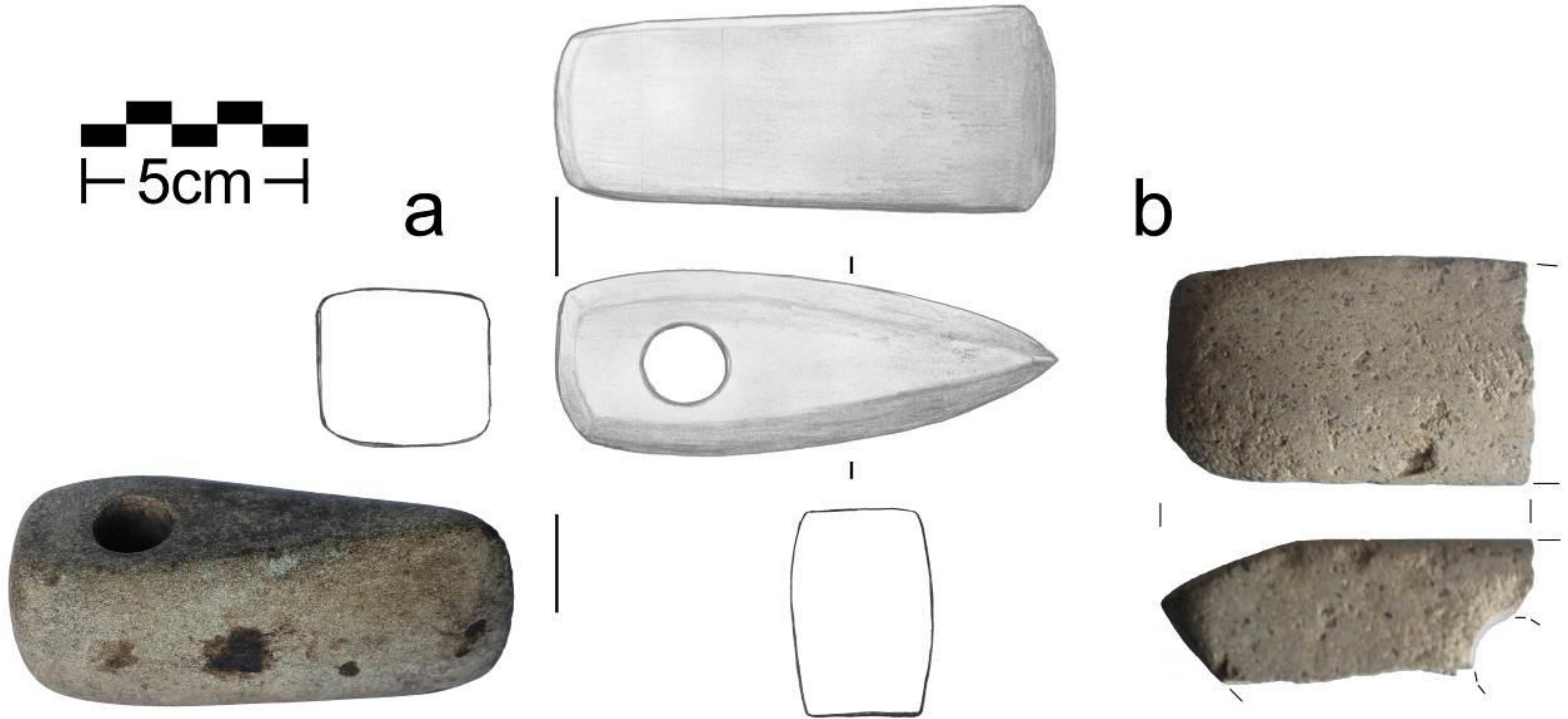

Figure 8. Polished and perforated stone axes from Răcătău. a) An intact axe from the location named Tău lui Anghel. b) A fragmented axe from Piatra Tomii Hill. Both artefacts are pictured at the same scale.

\subsection{Pit Features}

The 2009 excavations revealed what may be the remains of pit quarrying and heat cracked limestone. At many locations on the hill, one can observe depressions in the soil ranging from $1 \mathrm{~m}$ to $3 \mathrm{~m}$ width. Two of these were excavated in 2009. One was at the back edge of the terrace (and into the back wall) of Section 2 (Figure 9.a). The other was in Section 3 (Figure 9.b). Most had a layer of top soil of only 30-40cm thick. The lower soil in and around these depressions often contained organic residue. The rock surface in the depressions was highly cracked and loose. The pieces of rock ranged in size from sub-millimetric grains to gravel and up to $5-10 \mathrm{~cm}$ (with occasional larger pieces). It should be noted that most of the rock surfaces of the hill that were exposed or uncovered during excavation were of a waterworn or exfoliating type. The areas around the depressions which were not cracked had a large amount of gravel and small rock fragments just above the bedrock surfaces. Ceramic fragments were found in association with both features.
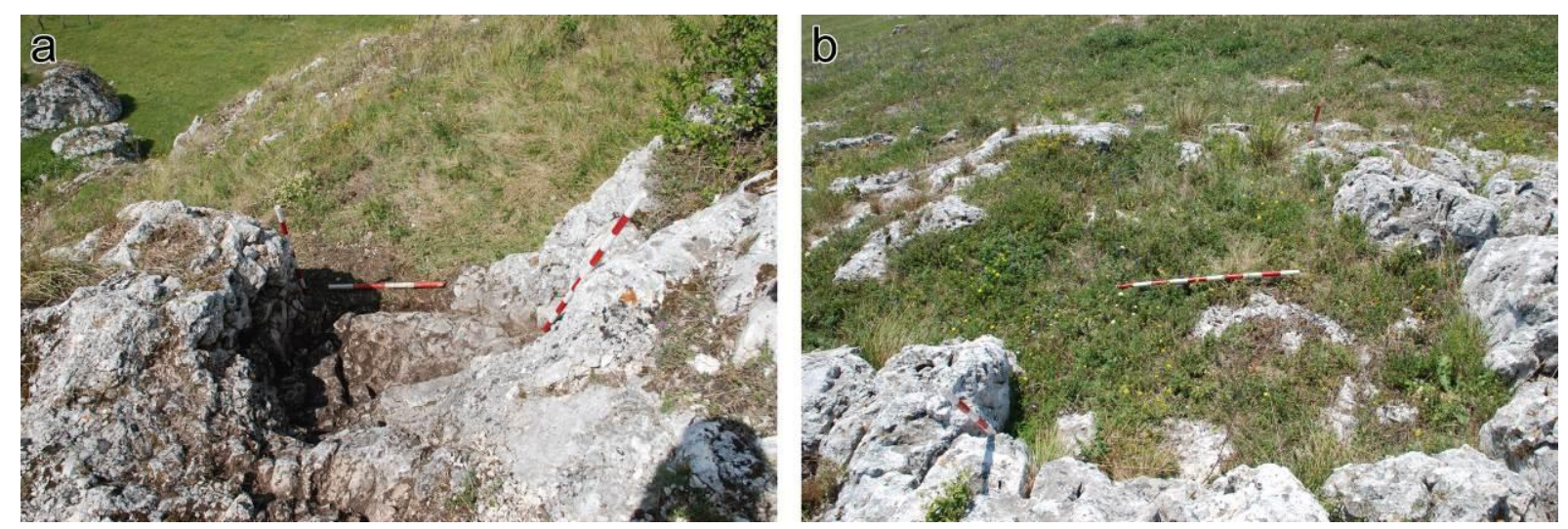

Figure 9. A possible quarrying pits. a) Section 2. b) Section 3.

\subsection{Coțofeni Hillside Dwellings}

Excavations in Section 1 revealed an interesting aspect of Coţofeni architecture. While excavating in this section, the research team determined that the natural slope (at least in this area) had been terraced with stones to create a step formation. Levelling was carried out with 
local limestone rocks which had been broken up. Beneath one dwelling the steps were about $30-40 \mathrm{~cm}$ per $10-15 \mathrm{~cm}$ increase in height. It was possible to identify two "levels" of this terrace. Above the stone bedding, a floor had been created from yellow clay. This floor formed the base of several dwelling, marked partially by a large quantity of burnt daub and other archaeological materials. Within the steps were post holes. This suggests that part of the dwelling facing downhill was supported by posts while the opposite part was placed directly on the ground. One of the dwellings benefited also from ovens. At the moment, it is difficult to precisely determine the extents of the surface dwellings, owing to the limited dimensions of the surface that was excavated.

This type of architecture represents something new for the Coţofeni culture. The terraces of inhabited rock outcrops have previously been identified, some even in the general area, in the Ampoi Valley, at the Poiana Ampoiului - Piatra Corbului site, for example. Those terraces intended for habitation however, were marked with a border of cobbles at the edge of the slopes (Ciugudean 2000: 18-19, pl. 139; 2001: 77). Other examples of terraces intended for habitation are known also in Coţofeni III sites in Transylvania, such as at Şincai - Cetatea Păgânilor (Lazăr 1980: 15-16; 1995: 251-252), Deva - Dealul Cetăţii (Balázs 1912; Rișcuța \& Țuțuianu 2003: 61) and from south of the Danube, for example at Crnajka (Tasić 1995: 66) and Klokočevac-Culmea Skiopuluj (Tasić 1995: 66, 137). A similar method of levelling a platform structure is used today in the modern villages nearby. (See Figure 10 for an example.)

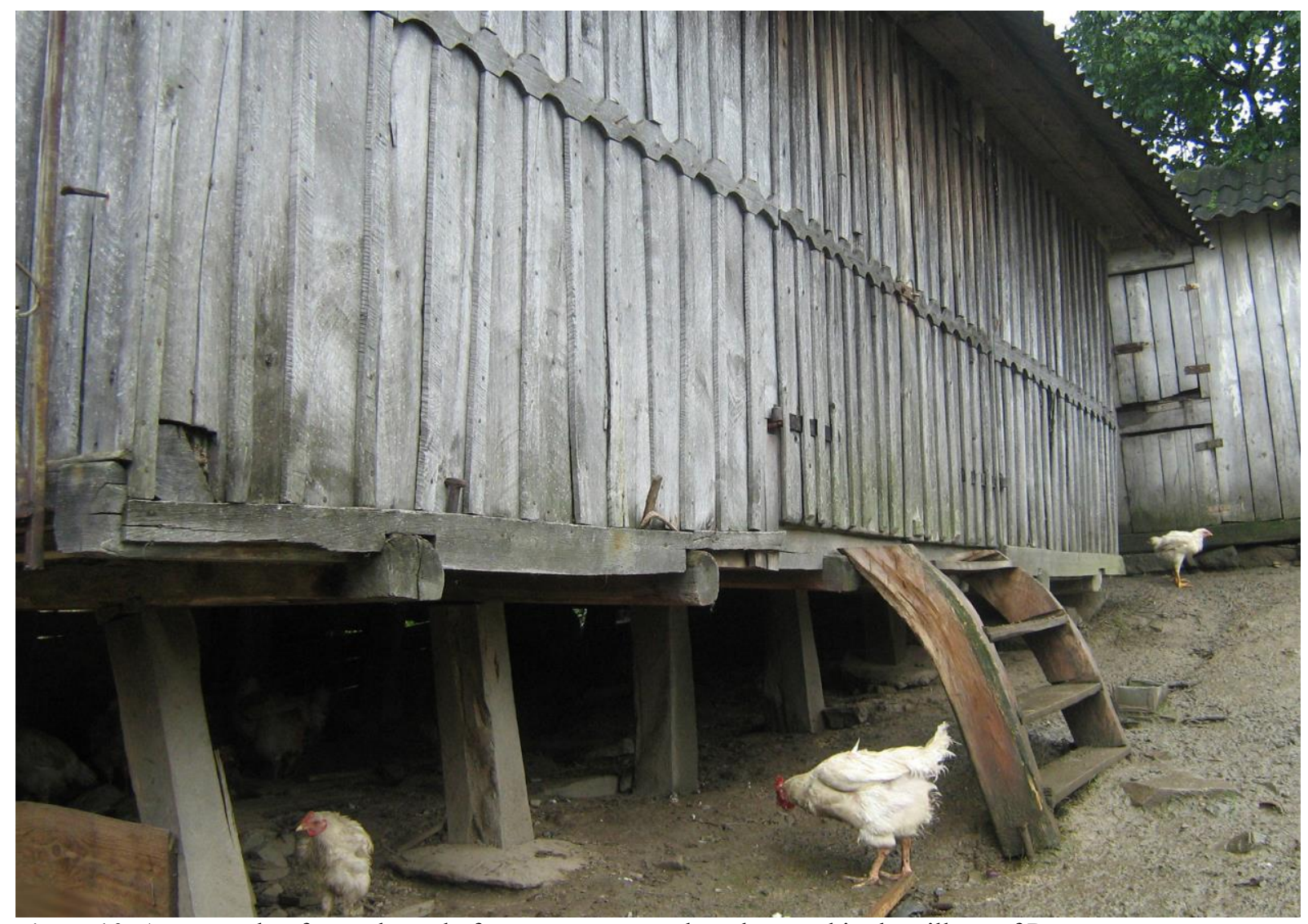

Figure 10. An example of a modern platform structure on sloped ground in the village of Răcătău. 


\subsection{Fine quality objects}

During the 2009 excavations several copper artefacts were found, including ear rings, beads and awls. Numerous ceramic cups and other fine quality ceramics were also discovered. (See Figure 11 for examples.)
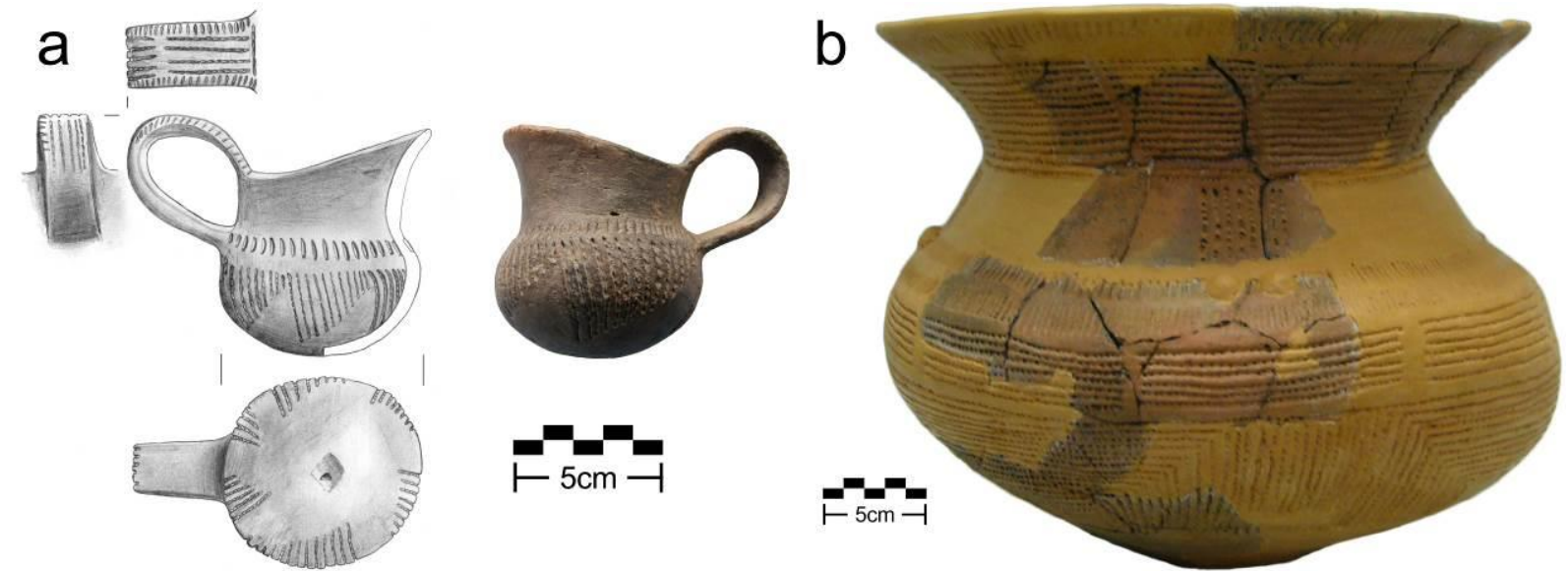

Figure 11. Two examples of a fine quality ceramics found at Piatra Tomii. a) A cup from Section 1. b) A pot from Section 2.

\section{Chert Characteristics}

The variety of chert found at Piatra Tomii has the same origin and physical characteristics as chert from other outcrops in the Trascău Mts. (particularly in the south). Trascău chert is found in or near to Late Jurassic limestone outcrops (most often karst towers) from around Piatra Tomii in the south and throughout the entire length of the Trascău Mts. (Lupu et al. 1966).

In terms of colour, this material is medium to dark browns, brown-grey, medium dark greys (almost black), and medium dark orangish-yellowish brown. In terms of Munsell colour codes, the chert from Piatra Tomii falls within the following ranges of colours - 7.5R-10R 2.5-3/1, 2.5YR-5YR 2.5-4/1, 5YR-7.5YR 5/8 to 4/6, 7.5YR-10YR between 5/1, 2.5/1 and $2.5 / 2,10 \mathrm{YR} 5 / 8$ to $3 / 6,2.5 \mathrm{Y}$ between $5 / 1,6 / 6$ and $2.5 / 1,5 \mathrm{Y} 2.5-6 / 1$, and $10 \mathrm{Y} 2.5-6 / 1$ (Munsell Color 2009). It is sub-translucent to translucent (occasionally being very opaque), with medium to fine grained surfaces with a matt (sometimes satiny or slightly waxy) lustre, and it often contains relics of its parent rock (limestone). Some samples show slight banding parallel to original lens orientation. (For explanations of descriptive terms, see previous publications by Crandell (for example, Crandell 2005; 2006).) This is likely caused by the original limestone sedimentary orientation. When broken, this material produced a good conchoidal fracture and sharp edges. (For examples, see Figure 12.) The darkness and intensity of the colour varies. Weathering may cause a white, opaque patina on the surface, as well as pitting. The patina may also obtain a bluish tint. Observations on chert in general in the Trascău Mts. have been made by previous researchers (Ilie 1950: 130; 1952; Ciupagea et al. 1970: 48-49; Crandell 2008; 2009; 2012).

Microscopically the main component of this material is microgranular quartz. (For examples, see Figure 13.) The grain size varies but except for rare in-filled cracks or voids, none of the grains are large enough to be seen with the naked eye or a loupe. The size is generally larger than that of flints which were imported into the region (which are also more equigranular than the chert found in the Trascău Mts.). The quartz rarely forms as microfibers or macrocrystals. In addition to quartz this material often contains large amounts of calcium carbonate, as large masses, as distinct clusters of particles, or spread throughout the material 
as small particles. This component is likely a remnant of the original parent material. The quantity of Fe oxide and hydroxide varies from little (or none) but is not nearly as abundant or concentrated it is in the jaspers of the Metaliferi and Trascău Mts. The Fe often tends to be blended with the quartz or to occur as small dark particles, sometimes clustered in an area. The iron content causes the orange and yellow colours that this material often exhibits. Some samples contain occasional dolomite rhomb-shaped crystals (for example, in Figure 13.b).
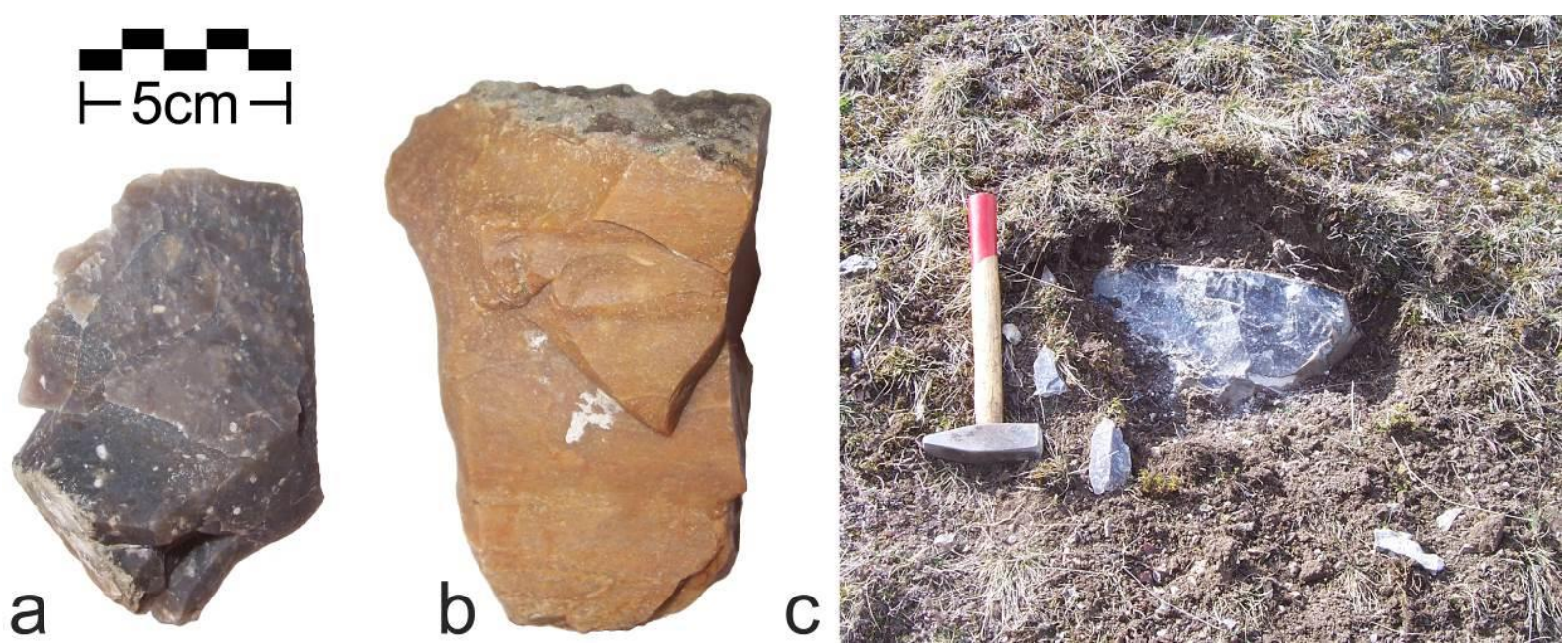

Figure 12. a) and b) Photos of chert samples from Piatra Tomii showing macroscopic variation. c) A nodule of chert in situ on the hill (the $2 \mathrm{~kg}$ hammer in the photo is for scale).

A few of the artefacts from the site were petrographically analysed to verify that they exhibited the same characteristics as the raw materials. They appear the same and there is no reason to doubt that they were not made from the locally available material. (See Figure 14 for an example.)

\section{Discussion}

\subsection{Chert Industry}

One of the objectives of the project was to learn more about the chert extraction and processing at the site. It is presumed that these were two of the primary occupations of this settlement. There are numerous outcrops of medium to high quality chert on the Piatra Tomii hill (which is in fact a late Jurassic karst tower with a thin layer of top soil covering it). Near the Piatra Tomii hill there are a few other smaller limestone outcrops, several of which also contain chert nodules and lenses. Indeed a large quantity of chert artefacts can be found on the surface at the site amongst potshards. In the excavation trenches of 2009, there were found several cores as well as fractured and whole blade blanks (unused blades). Petrographic analyses of the raw material at Piatra Tomii match those of the artefacts found at Neolithic and Chalcolithic sites in this region such as Tărtăria.

\subsection{Mining Technology}

One of the interpretations of these finds is that a form of fire-setting may have been used to extract the chert. After people located a band of chert or an area of large nodules, they would have covered the chert and built fires on top of the limestone to heat it up. They likely then would have swept away the embers and threw a large quantity of water on the still hot bedrock. (There are numerous springs within a few meters of the Piatra Tomii hill.) This would cause the rocks to shatter, making it easier to extract both the limestone rubble from around chert outcrops. (For a visual explanation, see Figure 15.) Stone axes and chisels may 
have been used to cut wood brought to the site. (Of course they were also likely used to cut and carve wood for constructions and other daily functions.) Without bronze or iron tools, it would have been time consuming and labour intensive to use only hammer stones to carve away at the limestone. This is not to say that they did not also use hammer stones (hand held or fixed in a handle), as percussion-worn river cobbles were also discovered during excavation of the hillside dwelling.

Although the limited excavations carried out so far are insufficient to determine with certainty that this was indeed what was happening at Piatra Tomii, the evidence so far shows similarities to the chert mining activities at Kleinkems (Germany) (Schmid 1980a; Diethelm 1997; Engel \& Siegmund 2005), Veaux-Malaucène (France) (Schmid 1980b) and Sélédin (France) (Roden 1983).
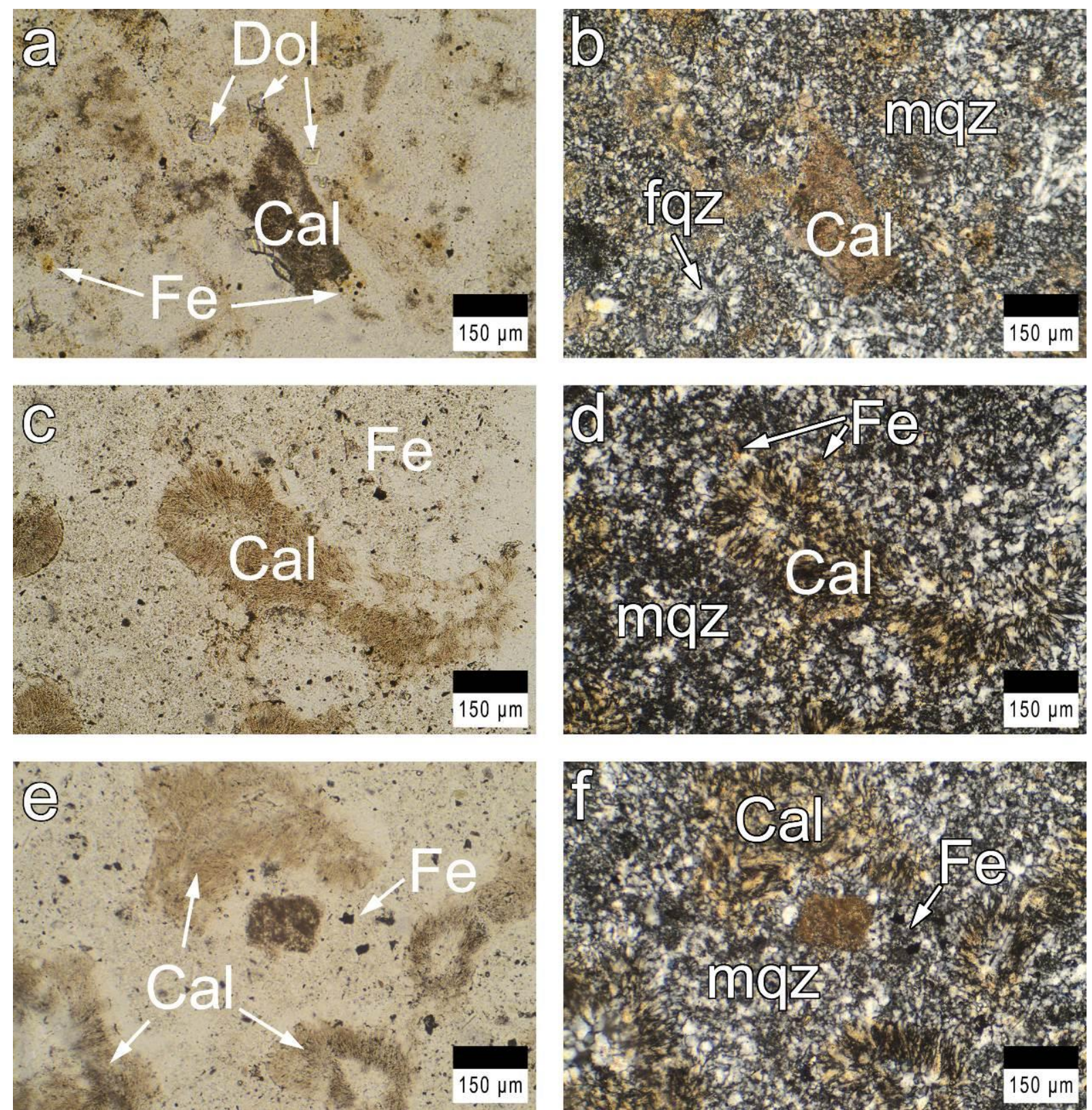

Figure 13. Microphotos (polarized light) of chert from Răcătău-Piatra Tomii. a) to f) Well developed microcrystalline quartz mixed with calcite and with small clusters of fibrous microquartz. Fe compounds are restricted to small areas. Left side, one polarizer (1P). Right side, the same with crossed polarizers $(+\mathrm{P})$. Abbreviations: mqz for microgranular quartz, fqz for fibrous quartz, Cal for calcite, Fe for iron phase, Dol for dolomite. 

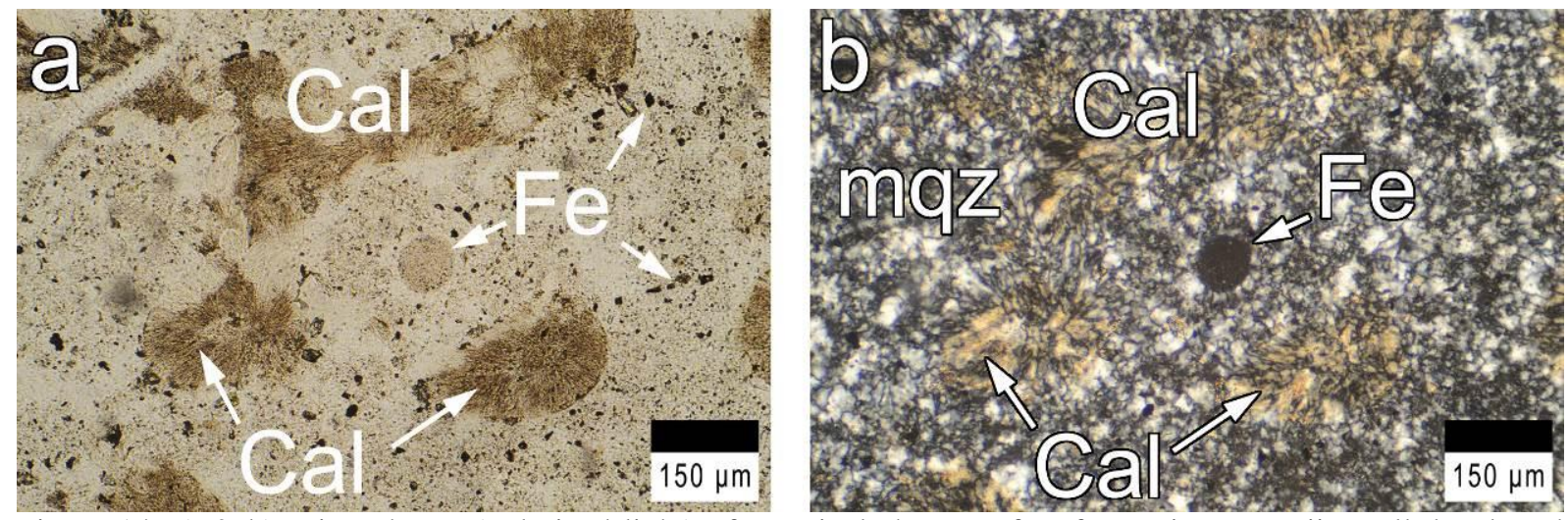

Figure 14. a) \& b) Microphotos (polarized light) of a typical chert artefact from Piatra Tomii. Well-developed microcrystalline quartz mixed with calcite; Small clusters of fibrous microquartz and Fe compounds restricted to small areas are seen. Left side, one polarizer (1P). Right side, the same with crossed polarizers $(+\mathrm{P})$. Abbreviations: mqz for microgranular quartz, Cal for calcite, Fe for iron compounds.

1.

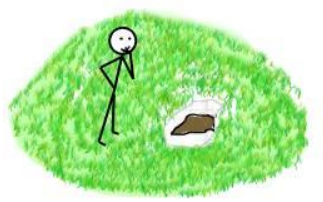

2.

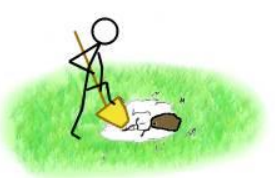

3.

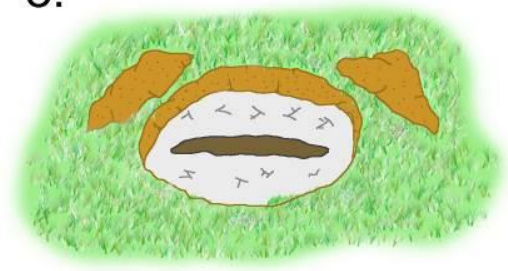

4.

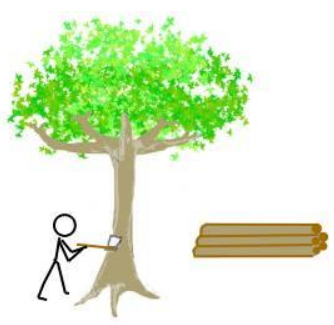

5.

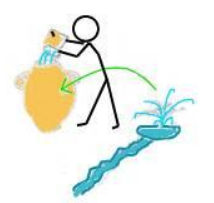

6.
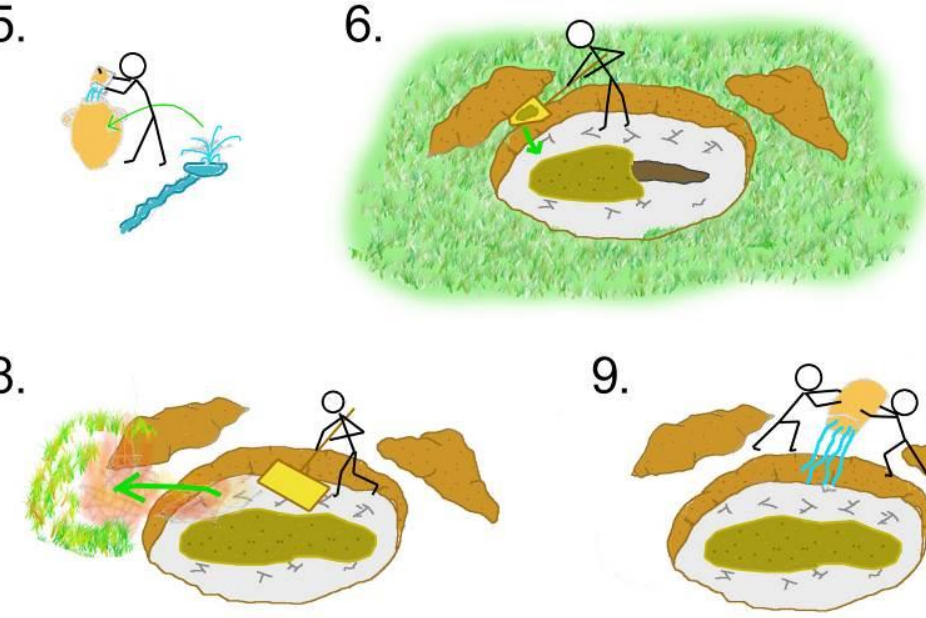

9.

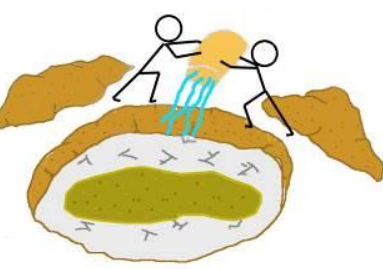

7.

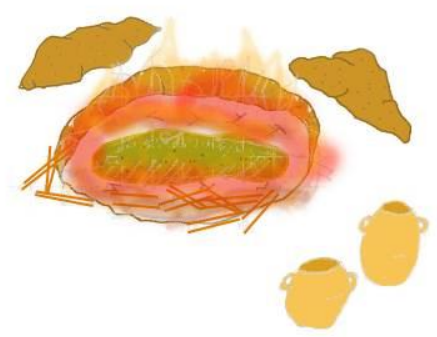

10.

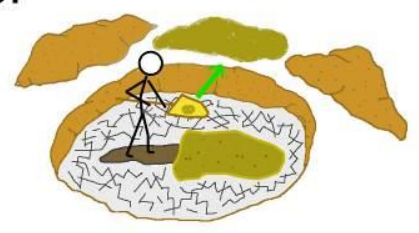

11.

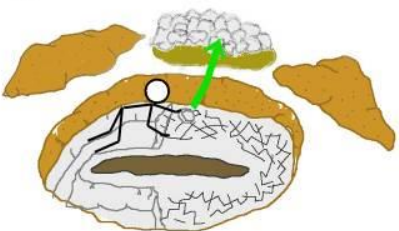

12.

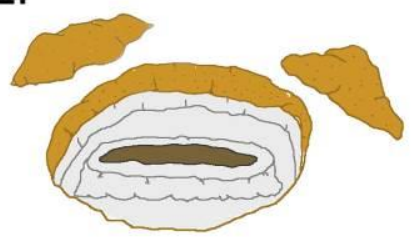

13.

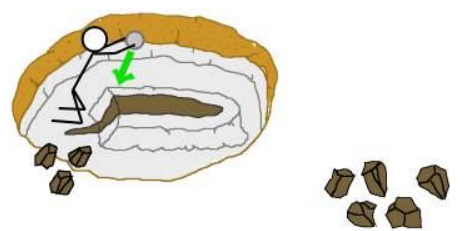

Figure 15. Diagram illustrating how chert can be mined by the fire-setting method. Stages: 1 . to 3 . finding and uncovering an outcrop of chert; 4 . collecting wood; 5 . collecting water; 6 . covering the outcrop with soil; 7. making a fire over the limestone bedrock; 8. removing the embers; 9. pouring water on the hot limestone; 10. uncovering the chert; $11 . \& 12$. removing the cracked limestone until only the chert band remains; 13 . removing the exposed chert. 
It should also be mentioned though that there are other possible explanations of the finds at this site. In Section 2, the carved rock face may have been part of a dwelling or other structure. It may have also been used by the people who lived there for easy access between the artificial terraces. The depression in Section one may have created to level the ground for a structure. It may also have been excavated to obtain rock for creating plaster or whitewash.

\subsection{Affluence}

It is worth noting that although the Piatra Tomii settlement is rather remote (in regards to distance from the Mureș Valley and in altitude) the occupants appear to have been more affluent than those living at other Coțofeni settlements in this region.

\subsection{Architecture}

Although this type of architecture has been observed in other cultures (and is still used today in the region) this is one of the first time that it has been observed at a Coțofeni site, suggesting a local evolution of the culture in its final phase. The presence of constructed dwellings also suggests permanent occupation (or repeated seasonal re-occupation) of this site by the same people.

\subsection{Connection to Other Sites}

At the mouth of the Răcătău Valley, where it opens into the Mureș Valley, across the Mureș River is the Tărtăria - Gura Luncii archaeological site (approximately $15 \mathrm{~km}$ from Piatra Tomii). At the Tărtăria site researchers have discovered Vinča, Petreşti and Coțofeni artefacts (Vlassa 1963; Paul 2011). Visual and petrographic analysis of the chert artefacts from Tărtăria show a match with the type of chert found at Piatra Tomii. It is quite possible that the inhabitants of Tărtăria obtained their chert from Piatra Tomii. Indeed, the outcrop at Piatra Tomii is the nearest source to Tărtăria. At present, it is unclear whether they visited Piatra Tomii for raw materials or traded for it. It is possible that the material used at Tărtăria and other nearby sites may have also come from other chert sources but those sources are further away. In addition to Tărtăria, there are various other sites in the Mureș Valley occupied by the Vinča (Suciu 2009), Petreşti (Paul 1992; Gligor 2000) and Coţofeni (Ciugudean 2000) cultures which may have had connection with and acquired chert from Piatra Tomii. (Several contemporary sites are indicated on the map in Figure 16.)

There are no sources of copper or copper ore at this site. The nearest sources of these would be to the north in the Ampoi Valley. Numerous Cotofeni settlements have been found in the Ampoi Valley (Ciugudean 2001). It is quite likely that the copper artefacts found at this site are from the Ampoi Valley but may have also come from other sources in the general region.

\section{Conclusions}

This site is significant for several reasons. These finds give us a technical insight into possible late Chalcolithic and early Bronze Age chert mining techniques. If the occupants of this site were indeed extracting the chert from the bedrock, then this site is the only chert quarrying settlement documented so far in the Transylvanian Basin. Regardless of whether the chert was being quarried or simply collected from previously eroded nodules of chert, this sites still gives us information regarding the beginning stages of lithic trade routes of the area. The collection and processing of raw materials represents the early stages of the chaine opératoire for lithic tools. 


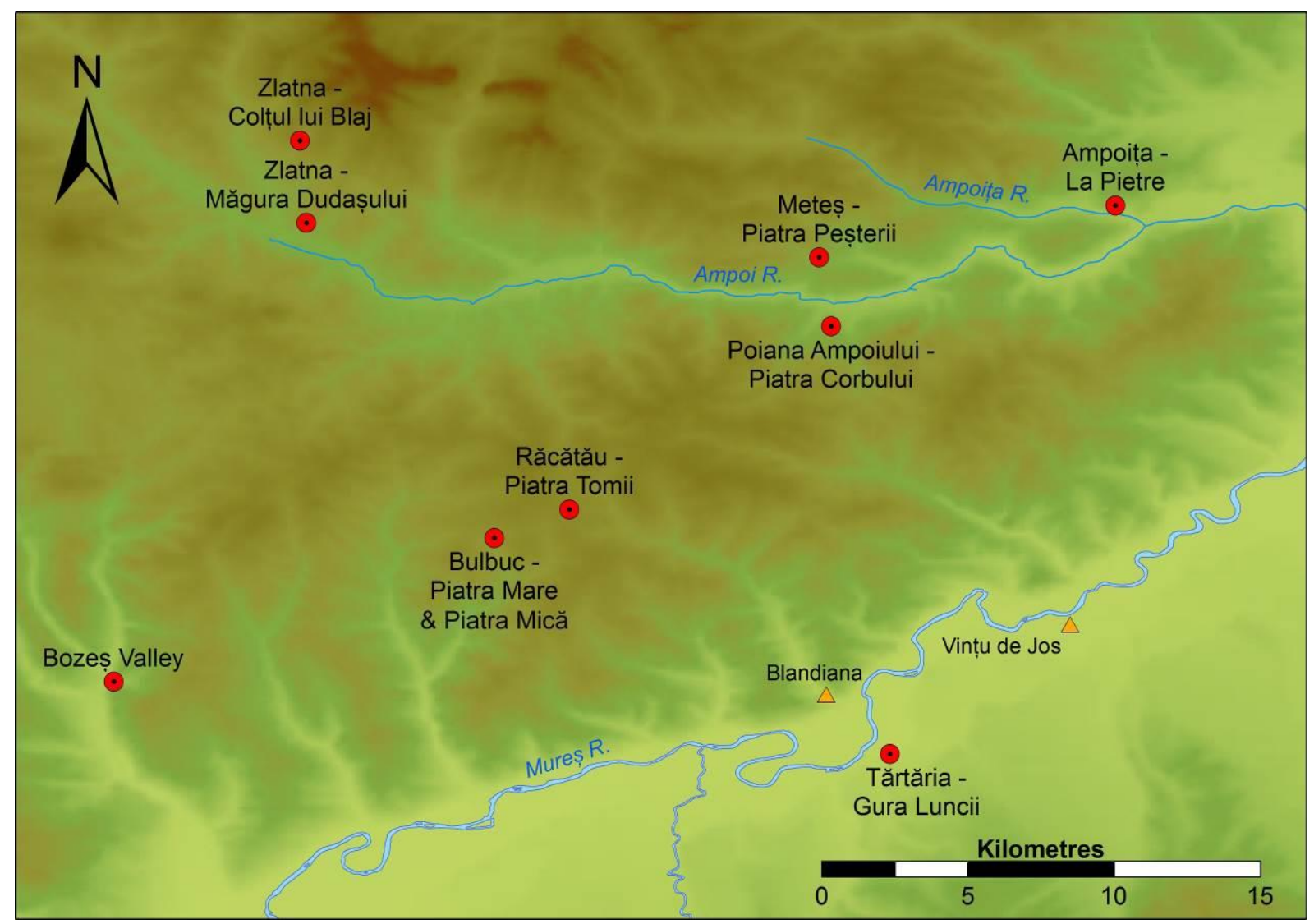

Figure 16. Map showing the location of Piatra Tomii relative to the Mureș and Ampoi Valleys as well as other contemporary archaeological sites (indicated by red circles on the map). (Modern settlements are indicated by triangles.)

The cores, unused blades, and the minimal use-wear on the lithic artefacts suggests that not only were the occupants of the settlement extracting raw material, but that they were producing tools at the settlement before and exporting the chert in the form of blank blades, cores or premade tools. It likely that they supplied contemporary lowland settlements in the Mureș Valley within 10 to $20 \mathrm{~km}$. Given its affluence, especially considering the relative isolation of the settlement, it is likely that the chert industry here was important to communities in the vicinity.

Although the majority of the artefacts so far found at the site are from the Cotofeni population, the presence of artefacts from earlier cultures at the settlement indicates that the site was already in use by the middle of the Neolithic by people of the Vinča and Petreşti cultures. Based on comparisons of Neolithic chipped stone artefacts found at nearby settlements with the geological material at Piatra Tomii as well as the nature of the preCoțofeni finds, it seems likely that the Vinča and Petreşti people who were at Piatra Tomii were there to exploit the chert source.

Since only a small percentage of this site has been excavated, it is also possible that remains of Vinča dwellings simply have not yet been found at Piatra Tomii. It is also possible, given the very shallow layer of soil above the bedrock, the steep slope of the hillside and the relatively small surface area, that most of the remains from the preceding settlement were intentionally removed when a new settlement was established in order to make room for new dwellings of the current inhabitants. Some materials may have also slid down the hillside due to erosion. This is one possible explanation for why very few remains of settlements prior to the last one were found on the hillside. 


\section{Acknowledgements}

The study was financially supported by funds from the Romanian Ministry of Education and Research projects PNII-ID 2241/2008 (CNCS-UEFISCDI) and PN-II-ID-PCE-2011-30881. The artefacts used in this study are housed at the "Iuliu Paul" Institute of Systemic Archaeology (Alba Iulia, Romania). Petrographic thin sectioning and analyses were carried out at the Geology Department of Babeş-Bolyai University. Thanks go to the students of "1 Decembrie 1918" University in Alba Iulia for their part in the excavations and fieldwalk surveys at the Piatra Tomii site.

\section{References}

Balázs, B. 1912, Adatok a dévai Várhegy őstörténetéhez. A hunyamegyei történelmi és régészeti társulat évkönyve, 21: 43-60. (in Hungarian) ("Information about the ancient history of Deva Castle Hill")

Ciugudean, H. 2000, Eneoliticul final în Transilvania și Banat: cultura Coțofeni. Bibliotheca Historica et Archaeologica Banatica Vol. 26. Mirton, Timișoara, 281 p. (in Romanian) ("The end of the Chalcolithic in Transylvania and Banat: The Coțofeni culture")

Ciugudean, H. 2001, Așezările culturii Coțofeni de pe valea Ampoiului. Patrimonium Apulense, 1: 71-81. (in Romanian) ("Settlements of the Coțofeni culture in the Ampoi Valley")

Ciupagea, D., Pauca, M. \& Ichim, T. 1970, Geologia Depresiunii Transilvaniei. Editura Academiei Republicii Socialiste România, Bucharest, 256 p. (in Romanian) ("Geology of the Transylvania Depression")

Crandell, O.N. 2005, Macroscopic analysis and characterisation of chert for provenance purposes. Sargetia, Acta Musei Devensis, 33: 137-153.

Crandell, O.N. 2006, Macroscopic and microscopic analysis of chert; A proposal for standardisation of methodology and terminology. Buletinul Cercurilor Științifice Studențești, 12: 7-30.

Crandell, O.N. 2008, Regarding the procurement of lithic materials at the Neolithic site at Limba (Alba county, Romania): Sources of local and imported materials. In: Geoarchaeology and Archaeomineralogy. Proceedings of the International Conference, 29-30 October 2008 Sofia. (Kostov, R.I., Gaydarska, B. \& Gurova, M., Eds.), Publishing House "St. Ivan Rilski”, Sofia: p. 36-45. Accessed: 05-JAN-2015. URL: http://mgu.bg/geoarchmin/naterials/06Crandell.pdf

Crandell, O.N. 2009, Romanian Lithotheque Project: Knappable stone resources in the Mureș Valley, Romania. Studia UBB, Geologia, Special Issue, MAEGS - 16: 79-80.

Crandell, O.N. 2012, Petrographic analysis of lithic artefacts from Limba (Romania) to confirm Neolithic trade patterns. Acta Mineralogica-Petrographica, Szeged, 7: 31.

Diethelm, I. 1997, Neolithic flint mining in the Three-Country Corner (Basel region), Kleinkems (Germany) and Löwenburg (Switzerland). In: Man and Flint. Proceedings of the VIIth International Flint Symposium, Warsawa-Ostrowiec Świętokryski (Schild, R. \& Sulgostowska, Z., Eds.), Institute of Archaeology and Ethnology Polish Academy of Sciences, Warsaw: p. 63-64.

Engel, F. \& Siegmund, F. 2005, Radiocarbon dating of the Neolithic flint mine at Kleinkems (near Efringen-Kirchen, District Lörrach, Baden-Württemberg, Germany). Antiquity (Project Gallery), 79(306). Accessed: 05-JAN-2015. URL: http://antiquity.ac.uk/projgall/siegmund306/ 
Giușcă, D., Bleahu, M., Lupu, M., Borcoș, M., Dimian, M., Lupu, D. \& Dimitrescu, R. 1967, Geological map of Romania, scale 1:200,000, Turda Sheet. Geological Institute of Romania, Bucharest. (in Romanian)

Gligor, M. 2000, Relația cadru geografic - habitat. Așezările aparținând culturii Petrești din bazinul Mureșului mijlociu. Apulum, 37(1): 133-149. (in Romanian) ("The geographic framework - habitat relationship. Settlements belonging to Petrești Cultures of the Middle Mures Basin"); Accessed: 05-JAN-2015.

URL: http://www.bcum.uab.ro/PDF_MIHAI/Mihai\%20Gligor_Apulum_2000_XXXV II_1.pdf

Ilie, M.D. 1950, Monts Métallifères de Roumanie; Recherches géologiques entre la Valea Stremţului et la Valea Ampoiului. Anuarul Comitetului Geologic, 23: 121-197. (in French) ("Metaliferi Mountains of Romania; Geological research between the Stremţ Valley and the Ampoi Valley")

Ilie, M.D. 1952, Cercetări geologice între Valea Cricăului și Valea Ampoiței (Alba). Dări de Seamă ale Ședințelor, 33 (1944-1945): 26-30. (in Romanian) ("Geological research between the Cricău Valley and the Ampoița Valley (Alba)")

Lazăr, V. 1980, Așezări de înălțime cu terase Coțofeni în Transilvania (III). Marisia, 10: 1130. (in Romanian) ("High Coțofeni îsettlements with terraces in Transylvania (III)")

Lazăr, V. 1995, Repertoriul arheologic al județului Mureș. Casa de Editură Mureș, Târgu Mureș, 477 p. (in Romanian) ("The archaeological repertory of the Mureș county")

Lupu, M., Borcoș, M., Dimian, M., Lupu, D. \& Dimitrescu, R. 1966, Geological Map of Romania, scale 1:200,000, 18 Turda Sheet. Romanian Geological Institute, Bucharest. (in Romanian)

Moga, V. \& Ciugudean, H. 1995, Repertoriul arheologic al județului Alba. Bibliotheca Musei Apulensis Vol. 2. Muzeul Naţional al Unirii Alba Iulia, Alba Iulia, 172 p. (in Romanian) ("The archaeological repertory of Alba district")

Munsell Color 2009, Munsell soil-color charts. Munsell Color, X-Rite, Grand Rapids, Michigan.

Paul, I.A. 1992, Cultura Petrești. Editura Museion, Bucharest, 208 (and 54 pl.) p. (in Romanian) ("The Petrești Culture")

Paul, I.A. 2011, Enigma tăblițelor de la Tărtăria - Schiță preliminară. Conferințele Bibliotecii ASTRA, 130: 9-73. (in Romanian) ("The enigma of the tablets from Tărtăria Preliminary outline"); Accessed: 05-JAN-2015.

URL: http://www.bjastrasibiu.ro/conferinte/130-iuliu.paul.pdf

Popa, C.I. 2012, Patrimoniul arheologic. In: Studiu privind aria caracteristică pentru peisaj cultural în zona Ceru-Băcăinți, județul Alba (Goronea, T., Pascaru, M. \& Popa, C.I., Eds.), Editura Mega, Cluj-Napoca: p. 12-19. (in Romanian) ("Archaeological heritage")

Rișcuța, N.C. \& Țuțuianu, C.D. 2003, Câteva considerații privind habitatul, arhitectura și designul interior la comunitățile Coțofeni. Sargetia, Acta Musei Devensis, 31: 61-68. (in Romanian) ("Some considerations regarding the habitat, architecture and interior design at Coțofeni communities")

Roden, C. 1983, Der jungsteinzeitliche Doleritbergbau von Sélédin (Côtes-du-Nord) in der Bretagne. Der Anschnitt. Zeitschrift für Kunst und Kultur im Bergbau Essen 35(3): 86-94. (in German) ("Late neolithic dolerite mining at Sélédin, Côtes-du-Nord, in Brittany")

Roman, P.I. 1976, Cultura Coțofeni. Biblioteca de Arheologie Vol. 26. Editura Academiei Republicii Socialiste România, Bucharest, 215 p. (in Romanian) ("The Coțofeni Culture") 
Roska, M. 1941, Az aeneolithikum Kolozskorpádi I. Jellegü emlékei Erdélyben. Közlemények az Erdélyi Nemzeti Múzeum érem- és régiségtárából, 1: 44-99. (in Hungarian) ("The Chalcolithic of Corpadea (Cluj) I. The nature of monuments in Transylvania")

Roska, M. 1942, Erdély régészeti repertóriuma. I. Öskor. Thesaurus antiquitatum Transsilvanicarum Vol. 1. Praehistorica. Erdélyi Tudományos Intézet, Cluj-Napoca, 376 p. (in Hungarian) ("The archaeological repertory of Transylvania. I. Prehistory")

Schmid, E. 1980a, Der jungsteinzeitliche Abbau auf Silex bei Kleinkems, BadenWürttemberg (D1). In: 5000 Jahre Feuersteinbergbau; Die Suche nach dem Stahl der Steinzeit (Weisgerber, G., Slotta, R. \& Weiner, J., Eds.), Deutsches Bergbau-Museum, Bochum: p. 141-165. (in German) ("The Neolithic flint mining at Kleinkems, BadenWürttemberg (D1)")

Schmid, E. 1980b, Der Silex-Bergbau bei Veaux-Malaucène in Südfrankreich (F1a, b). In: 5000 Jahre Feuersteinbergbau. Die Suche nach dem Stahl der Steinzeit. (1st Editiion 1980, 3rd Edition 1999) (Weisgerber, G., Slotta, R. \& Weiner, J., Eds.)

Veröffentlichungen aus dem Deutschen Bergbau-Museum Bochum Vol. 22, Deutsches Bergbau-Museum, Bochum: p. 166-178. (in German) ("The flint mines at Veaux-Malaucène in southern France $(\mathrm{F} 1 \mathrm{a}, \mathrm{b}) ")$

Suciu, C.I. 2009, Cultura Vinča în Transilvania. Biblioteca Brukenthal Vol. 44. Editura Altip, Alba Iulia, 304 p. (in Romanian) ("The Vinča culture in Transylvania")

Tasić, N. 1995, Eneolithic cultures of central and west Balkans. Special Edition (Institute for Balkan Studies, Serbian Academy) Vol. 61. Draganić, Belgrade, 205 p.

Téglás, G. 1901, Öskori, római és népvándorláskori emlékek. In: Az Osztrák-Magyar Monarchia írásban és képben Vol. 20 (von Habsburg-Lorraine, Rudolf, Ed.), A Magyar királyi államnyomda kiadása, Budapest. (in Hungarian) ("Prehistoric, Roman and migration period monuments"); Accessed: 05-JAN-2015.

URL: http://www.tankonyvtar.hu/hu/tartalom/tkt/osztrak-magyar/ch18s02.html

Téglás, G. 1902a, Denkmäler der Urzeit, Römerzeit und Völkerwauderungszeit. In: Die Österreichisch-ungarische Monarchie in Wort und Bild Vol. 23 (von HabsburgLorraine, Rudolf, Ed.), Die kaiserlich-königliche Hof- und Staatsdruckerei, Vienna: p. 19-36. (in German) ("Prehistoric, Roman and migration periods monuments")

Téglás, G. 1902b, Hunyadmegye őstelepelnek vázlatos áttekintése. In: Hunyadvármegye földjének története: Az öskortól a honfoglalásig Vol. 1 (Kuun, G., Torma, Z. \& Téglás, G., Eds.), Athenaeum, Budapest: p. 8-22. (in Hungarian) ("Hunedoara region schematic overview of prehistoric sites")

Vlassa, N. 1963, Chronology of the Neolithic in Transylvania, in the light of the Tărtăria settlement's stratigraphy. Dacia, 7: 485-495. 